Instructions for authors, subscriptions and further details:

http://rasp.hipatiapress.com

\title{
Depressive Symptoms in Elderly People Participating in University of the Third Age and Residents of Nursing Homes: the Role of Optimism and Acceptance of Passing
}

Edyta Idczak-Paceś, Adrian Kabat, Adrianna Krzywik, \& Iwona Nowakowska

The Maria Grzegorzewska University, Warsaw (Poland)

Date of publication: July $30^{\text {th }}, 2021$

Edition period: July 2021 - January 2022

To cite this article: Idczak-Paceś, E., Kabat, A., Krzywik, A. \& Nowakowska, I. (2021). Depressive symptoms in elderly people participating in University of the Third Age and residents of Nursing Homes: the role of optimism and acceptance of passing. Research on Ageing and Social Policy, 9(2), 105-132. http://10.4471/rasp.2021.5782

To link this article: http://dx.doi.org/10.447/rasp.2021.5782

\section{PLEASE SCROLL DOWN FOR ARTICLE}

The terms and conditions of use are related to the Open Journal System and to Creative Commons Attribution License (CCAL). 


\section{Depressive Symptoms in Elderly People Participating in University of the Third Age and Residents of Nursing Homes: the Role of Optimism and Acceptance of Passing}

\section{Abstract}

The elderly age group needs particular support in preventing development of depressive symptoms, among others, due to the prospect of passing. This group is heterogeneous in terms of characteristics of ways of spending leisure time, which, as an important aspect of everyday life affecting the quality of interpersonal relationships and well-being, might be related to the level of their depressive symptoms. The aim of this study was to find out whether participation in University of Third Age (UTA; leisure time spending directed at personal development) activities versus being a Nursing Home resident $(\mathrm{NH}$; leisure time spending, directed at compensation of difficulties associated to the aging process) may differentiate elderly people in terms of the level of depression taking into account their optimism and acceptance of passing. The study was paper-pencil questionnaire-based, conducted on a sample of people above the age of 59: participants of UTA $(\mathrm{N}=48)$ and $\mathrm{NH}(\mathrm{N}=54)$. In the UTA group, consistently for all levels of acceptance of passing, the higher the level of optimism, the lower the depressive symptoms. However, for the NH group, the higher the acceptance of passing, the lower the role of optimism in predicting depressive symptoms.

Keywords: acceptance of passing, depression, Nursing Home, optimism, University of Third Age 


\section{Síntomas Depresivos en Participantes de la Universidad de la Tercera Edad y en Residencias de Ancianos: el Optimismo y la Aceptación de la Muerte}

\section{Resumen}

Los mayores necesitan un apoyo especial para la prevención de síntomas depresivos, debido a la inevitable perspectiva de la muerte. Este grupo es heterogéneo en cuanto a las formas de pasar el tiempo libre, un aspecto importante de la vida diaria vinculado al bienestar y la calidad de relaciones interpersonales, así como un posible factor en el nivel de síntomas depresivos. El estudio pretende verificar si la participación en actividades de la Universidad de la Tercera Edad (UTE; tiempo libre dirigido al desarrollo personal) versus vivir en una Residencia de Ancianos (RA; tiempo libre orientado hacia aliviar las dificultades de la edad) puede ser elemento diferenciador del nivel de depresión en los ancianos, considerando su optimismo y aceptación de la muerte. La investigación se basa en encuestas papel-lápiz, realizadas en una muestra de mayores a los 59 años de edad: participantes UTE $(\mathrm{N}=48)$ e ingresados $\mathrm{RA}(\mathrm{N}=54)$. En el grupo UTE, cuanto más alto el nivel de optimismo, más bajo el de los síntomas depresivos, para todas las franjas de aceptación de la muerte. Para el grupo RA, cuanto mayor la aceptación del paso del tiempo, menos influirá el optimismo en predicción de síntomas de depresión.

Palabras clave: aceptación de la muerte, depresión, Residencia de Ancianos, optimismo, Universidad de la Tercera Edad 


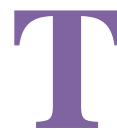

he prospect of death becomes increasingly clear in old age. In this developmental period people imagine the scenarios of passing and be associated with positive or negative feelings (Deręgowska, 2014). Awareness of passing and the ending of life has an impact on increasingly frequent thoughts about one's own and one's loved ones' upcoming death, which can contribute to a person's sense of quality of life, fear of death and depression.

Erik Erikson (1968), in his seminal work, presented eight stages of human life from infancy to late old age and their crises. At each of these stages, a person faces a developmental challenge that obliges them to master new skills and overcome a specific problem. The way in which a given developmental crisis is dealt with affects the resolution of subsequent ones. According to Erikson, the period of late adulthood and old age is the last, eighth crisis, i.e., the integration of ego versus despair. Despair at the changing turn of human life, and especially at the fragility of human existence in the face of death. A person at this stage of development needs to reflect and balance his or her life. A person at this developmental stage often strives to consolidate and accept own life, all failures and successes as well as determines their own life's purpose and sense. Successfully dealing with this crisis means that one will achieve a sense of internal harmony and a belief in the sense and purposefulness of life, which allows one to calmly prepare for its end. During coping with this crisis, a person may feel sad, depressed and, importantly, experience strong fear of death (Erikson, 1968, 1982). Fear of death (tanatophobia), which usually does not interfere with everyday life and can even make these people live more consciously, can contribute to the development of depression (for a review of the meaning of Erikson's theory in death attitude formation see Sękowski, 2020).

Depression is one of the most common mental disorders among the elderly (Fidecki et al., 2019; Mamplekou, 2010). A depressive episode is diagnosed when the patient suffers from depressed mood, energy depletion, and decreased activity (WHO, 2019). Feelings of pleasure are reduced, the range of interests and concentration are reduced, and significant fatigue often occurs, even after a small effort. Sleep is usually disturbed and the appetite is reduced. Self-esteem and self-confidence are almost always lowered, and feelings of guilt and low value arise. Depressed mood is independent of current events, does not change much in subsequent days, and may be 
accompanied by somatic symptoms. Depending on the number and severity of the symptoms, the depressive episode can be described as mild, moderate or severe.

In seniors the most common depression is so-called reactive depression, which is usually a response to difficult, traumatic events such as: death of a spouse, loss of a loved one, exile or loneliness as well as family conflicts and facing disability and loss of physical strength due to aging processes. These examples of external factors are much more likely to trigger depression in people over 65 years of age. Compared to younger people, depression in seniors is less common, but the severity of disease symptoms is greater (KaslGodley et al., 1998). Depression in the elderly is also associated with an increased risk of death and disability, since seniors more often attempt suicide than young adults (Rodda et al., 2011). When it comes to differences in the frequency of depressive symptoms due to gender, the level of depression in women is higher than in men (age range 50-60 years). Over 80 years of age these differences are blurred. The dynamics of depressive symptoms in men is different than in women. It increases at the age of 60-80 years, while women in this age range see no change. Differences in the level of severity of depression symptoms between the sexes also blur after the age of 80 (Heikkinen et al., 2004). Depression and depressive symptoms are the most common mood disorders among the elderly (Blazer, 2009). In institutionalized older people, the phenomenon of depression is a serious emotional problem (Djernes, 2006). Seniors living at home are less exposed to depression compared to those in institutionalized facilities (Wang, 2001).

Understanding the factors that might promote or prevent elderly people from developing depressive symptoms is crucial to plan strategies for improving the quality of life of elderly people and professional mental health care (Sivertsen et al., 2015).

\section{Optimism as a Form of Mental Resiliency and Factor Protecting against Depression in the Elderly}

Carver and Scheier (2010) created one of the best-known theories of optimism. Optimism understood in this way is the generalized expectation of the individual regarding his own actions; it might also be related to self-esteem (Duy \& Yildiz, 2019). According to Sethi \& Seligman (1993), it has a positive effect on our health and promotes effective coping with stress (Poprawa, 
2001). It has also been proven many times to protect the influence of optimism as a factor in preventing depressive symptoms (Sethi \& Seligman, 1993). In general, optimism has a very positive effect on human health areas, including, for example, faster recovery after medical procedures (Fitzgerald et al., 1993) or contributing to lower mortality (Maruta et al., 2000)

The concept of resiliency or mental resiliency is most often understood as the individual's ability to adapt and respond adequately to difficult situations. Mental elasticity, understood in this way, refers to the theory of ego-resilience. Block (1996) describes it as a relatively permanent disposition that determines the phenomenon of flexible adaptation to the changing requirements that life brings. Therefore, mental resiliency can be seen as a multidimensional construction that involves the use of environmental factors and support systems in coping with stress (Werner, 1993). Mental resiliency is positively correlated with the level of life satisfaction (Ogińska-Bulik, 2014; Beutel et al., 2009; Chung, 2008). Psychological well-being is also connected to personality traits, such as extraversion and low neuroticism, and to a lesser extent agreeableness, diligence as well as openness to experience. The way in which older people think about themselves and the world, their hope, optimism, and sense of control (Diener et al., 2002) are also connected to their sense of well-being. A person with a high degree of resiliency is more positive about life, has emotional stability, considers himself a person who influences decision-making and also considers any difficulties encountered in the category of opportunities to gain new experiences (Ogińska-Bulik \& Juczyński, 2010, 2011). Charney (2004) in their study confirmed the protective role of resiliency, pointing to its negative relationship with various measures of maladjustment, such as anxiety disorder, social phobia, depression. People who experience stressful life events can change their way of looking at the world, find hope and look for other ways to solve their problem, which is beneficial for their mental health processes (Fredrickson, 2001).

According to J. Makselon, at the end of their lives, seniors are faced with forming an attitude towards their own death. They can accept the passing of time in peace, indifference or skepticism, or displace all thoughts of the inevitable (Makselon, 1981; Feifel, 1990). Fear of passing away may be related to depression, mourning and avoiding death (Mercês et al., 2019; Mohammadpour et al., 2019). Health assessment may also play a role in fear of death in the elderly adults (Brudek et al., 2019). Therefore, it seems 


\section{Depressive Symptoms, Optimism and Acceptance of Passing}

necessary that in the last stages of life the individual should be able to face the difficulties associated with the fear of death (Lonetto \& Templer, 1988).

Research by Arbinaga (2003) did not show significant differences in the perception of their own death in seniors over 60 years of age in terms of place of residence. Similar results were obtained both in the group of persons living independently and those staying under the care of institutions. Recent studies, however, see some differences between these study groups. According to Moreno (2009), institutionalized people have less fear of death than noninstitutionalized seniors. The author combines this data with a possible higher exposure to the reality of death in the institution.

Based on literature on the possible associations of characteristics of spending leisure time and depressive symptoms in elderly adults (Dupuis \& Smale, 1995; Fine, 2001), we decided to investigate whether participation in voluntary leisure time activities in the elderly age (in Universities of the Third Age, UTAs) or involuntary leisure time spending characteristic for residents of Nursing Homes, NHs, might differentiate elderly people in terms of their level of depressive symptoms when taking into account constructs relevant for preventing depression in the elderly: optimism as a form of resiliency (Giltay et al., 2006; Reker, 1997) and acceptance of passing (Moreno et al., 2009).

\section{Contrasting Examples of Spending Leisure Time in the Elderly Age: Universities of the Third Age and Nursing Homes}

Seniors undertake various activities, which differentiate them in terms of their lifestyles. Life history and experiences, cognitive age, level of education and family background might have an impact on how seniors live their elderly life (Iyer et al., 2008; Thomas \& Peters, 2009). The possibility to control one's own life in terms of choosing one's lifestyle, as well as activities to be undertaken might be associated with a lower risk of developing depression (Pot et al., 2010). Universities of the Third Age are examples of a special form of activity, in which people voluntarily choose to develop skills and competencies in a selected area (Formosa, 2010). Students of UTA can benefit from a variety of courses, as well as from socializing and the possibility to get to know new people in their age range, with whom they share their passions (Formosa, 2010; Villar \& Celdran, 2012). Such activity might prevent the development of depressive symptoms through participation in social life and enhancing positive development in the elderly (Formosa, 2014; Ondrakova, 
2014). However, residents of Nursing Homes live within an institution, which implies rigid, externally organized activities, in which they often take part due to obligation, not due to choice. The activities are often planned so as to compensate for the deficits observed in the elderly age instead of focusing on the development of new competencies of interest of the residents. An observational study by den Ouden et al., (2015) revealed that residents of nursing homes are physically inactive, which further contributes to feelings of depression. Research suggests that institutionalized care for elderly persons might contribute to greater depression (Anstey et al., 2007; Chiang et al., 2010; Salguero et al., 2011) due to, for instance, deficits of satisfactory social contact and decreased hope for the future.

\section{Current Study}

The main aim of this study was to find out whether acceptance of own passing might moderate the relationship between optimism and depressive symptoms in seniors who participated in University of the Third Age or were residents of a Nursing Home.

Drawing on the theoretical assumptions, as well as the empirical research available in the literature, we hypothesize the following:

H1. Optimism is negatively related to general depressive symptoms in seniors.

$\mathrm{H} 2$. Being a UTA student or a NH resident has an impact on depressive symptoms (Brown et al., 2002; Volicer et al., 2012; Harris \& Cooper, 2006; Hoover et al., 2010; Irigaray \& Schneider, 2007; Zielińska-Więczkowska et al., 2011). UTA students are lower on depressive symptoms compared to NH residents. UTA participation might lower the risk of developing depressive symptoms and also, due to its character, be chosen by people lower on depressive symptoms. Furthermore, being a UTA student is connected to freedom of choice of activities and sense of development, not compensation of cognitive or physical deficits connected with elderly age. Moreover, being a NH resident implies being a consumer of the institutionalized care system with a focus on compensation rather than development, which is a valid predictor of developing depressive symptoms.

$\mathrm{H} 3$. Acceptance of passing moderates the relationship between being a UTA student/a NH resident and optimism/depression, so that for UTA students the higher the optimism and acceptance of passing, the lower the 


\section{Depressive Symptoms, Optimism and Acceptance of Passing}

depressive symptoms. The hypothesized pattern will also be visible for $\mathrm{NH}$ residents; however, the moderation effect will be weaker due to the fact that NHs and institutionalized care do not create as much sense of development and positive direction towards the future as participation in UTA. Optimism and acceptance of passing are reported to be interrelated constructs, given that optimistic attitudes towards life might be associated with acceptance of what comes in life (Zadworna-Cieślak \& Ogińska-Bulik, 2019). Passing is an inevitable element of life for the elderly, therefore accepting it and looking optimistically to the future regardless of this might prevent individuals from giving in to feelings of depression and sadness (Daaleman \& Dobbs, 2010). Therefore, the predictive validity of optimism and acceptance of passing on depressive symptoms in both investigated groups might stem from the interplay of these constructs.

\section{Method}

\section{Procedure}

The study was conducted in face-to-face, individually, on two groups of elderly adults (over 59 years old). Although people in late adulthood and old age are defined as people over 65 , the authors of this article have adopted the age of 59 as a test criterion. 1 consisted of students of University of the Third Age (UTA), whose participation in the UTA activities was voluntary. Group 2 consisted of residents of a Nursing Home (NH), whose daily activity was rigid and imposed. All surveys were collected by the same person. Before the surveying procedure, the respondents were informed about its purpose and instructions for answering individual questionnaires were read to them. All participants provided informed consent prior to completing the surveys. The study was confidential. No personal data enabling identification of individuals were gathered. For medical reasons (lowering the function of cognitive processes), some seniors read the questionnaire questions and their answers were entered by the researcher on the sheet. It should be noted that for the $\mathrm{NH}$ only those persons whose intellectual capacity enabled them to understand the questions, as indicated by an employed psychologist/pedagogist, participated in the study. The study was conducted in Łódź, Poland. 


\section{Note on Collected Data}

Parts of the dataset regarding resiliency that was used for the preparation of this paper became a subset of a larger database available at Open Science Framework (Zadworna et al., 2019).

An article testing different hypotheses and based (among other datasets) on the dataset that was used for the preparation of this paper was already published (Zadworna-Cieślak \& Ogińska-Bulik, 2019).

\section{Measures}

Depression. Depression was measured using the Geriatric Depression Scale questionnaire GDS-SF (short 15-item form), by Sheikh \& Yesavage (1986). The GDS is a self-report questionnaire and, at the same time, an accurate and reliable screening tool for assessing the severity of depressive symptoms in older people (over 65 years of age). The questionnaire is not a clinical diagnosis, but only allows the risk of depression occurrence to be estimated and therefore cannot replace a clinical history or a complex diagnosis process; however, it might be used for research purposes. Respondents answer yes or no to questions. The score for GDF-SF is as follows: 0-5 points - no depression; 6-15 points - increased risk of depression.

Acceptance of passing. Level of fulfilling developmental tasks was assessed with the Acceptance of passing subscale in the Developmental Tasks Questionnaire for Seniors (KZR-S) by Zadworna-Cieślak (2017, 2019). It is a 15 -item scale regarding the assessment of realization of various life tasks in late adulthood. The scale consists of 3 subscales: Acceptance of own life (satisfaction with past and present life, positive thinking about own life and being directed at development), Adaptation (the ability to adapt to changes typical for older age such as a decrease in physical strengths, retirement and adaptation of own needs to lowered income), and Acceptance of passing (concerning the problem of accepting the inevitability of aging and perspective of own and close others' death). Responses are marked on a 5point Likert-type scale ranging from 1 - definitely not to 5 - certainly yes.

Optimism. Optimism was measured using the Resiliency Measurement Scale (SPP-25; Ogińska-Bulik \& Juczyński, 2008) Optimism subscale. As a whole, SPP-25 is a 25 -item scale measuring the overall resiliency level 


\section{Depressive Symptoms, Optimism and Acceptance of Passing}

(mental agility, resistance), treating this construct as a personality trait. It encompasses 5 subscales reflecting five components of resiliency: Determination and persistence in action; Openness to new experiences and sense of humor; Competencies to cope and tolerance of negative affect; Tolerance of failures and treating life as a challenge; Optimistic life attitude and ability to mobilize in difficult situations. Responses are marked on a 5point Likert scale ranging from 0 - definitely not to 4 - certainly yes.

Controlled sociodemographic variables. A sociodemographic survey of own construction was distributed to the participants, encompassing data about age, gender, marital status, having children, education, having a job, being retired, material situation, and having a chronic illness.

\section{Participants}

If not otherwise stated, the percentages above indicate the percentage of responses in a particular group.

The UTA group comprised 48 people ( $47.1 \%$ of the total sample), 9 males $(18.8 \%), 39$ females $(81.3 \%)$, age range 59-76, Mage $=69.00$, SDage $=4.46$. 5 participants had never been married (10.4\%), 24 were married $(50.0 \%), 18$ (37.5\%) widowed, and 1 participant $(2.1 \%)$ did not provide information about marital status. 39 participants $(81.3 \%)$ had children, 9 (18.8\%) did not. 2 participants (4.2\%) finished their education at a vocational level, $28(58.3 \%)$ at high school, 17 (35.4\%) at higher education, and 1 participant $(2.1 \%)$ did not provide information about it. 3 participants $(6.3 \%)$ reported having a job during the survey time. 42 participants $(87.5 \%)$ declared being retired during the survey time; the minimum number of years of retirement was 1 , maximum 28, Myears among the retired $=12.84$; SDyears among the retired $=6.47$. 1 participant $(2.1 \%)$ rated their material status as very good, $15(31.3 \%)$ as good, 31 participants $(64.6 \%)$ as average, 1 participant $(2.1 \%)$ as bad. 22 participants (45.8\%) had a chronic illness, 20 (41.7\%) had not and $6(12.5 \%)$ did not respond to this question.

The NH group comprised 54 people (52.9\% of the total sample), 19 males (35.2\%), 35 females $(64.8 \%)$, age range 61-94, Mage $=79.69$, SDage $=7.27$. 13 participants were never married $(24.1 \%), 4$ married $(7.4 \%), 35(64.8 \%)$ widowed, and 2 participants $(3.7 \%)$ were divorced. 32 participants $(59.3 \%)$ had children, while $22(40.7 \%)$ did not. 12 participants $(22.2 \%)$ finished their education at a basic level, 11 participants $(20.4 \%)$ at a vocational level, 21 
(38.9\%) at high school, $9(16.7 \%)$ at higher education, and 1 participant (1.9\%) did not provide information about it. 3 participants (5.6\%) reported having a job during the survey time. 49 participants $(90.7 \%)$ declared being retired during the survey time; the minimum number of years of retirement was 4, maximum 45, Myears $=21.31 ;$ SDyears $=8.87 .1$ participant $(1.9 \%)$ rated their material status as very good, $12(22.2 \%)$ as good, 27 participants $(50.0 \%)$ as average, 12 participants $(22.2 \%)$ as bad, 1 participant (1.9\%) as very bad, and 1 participant (1.9\%) did not rate their material status. 36 participants $(66.7 \%)$ had a chronic illness, 17 (31.5\%) did not, and 1 participant (1.9\%) did not respond to this question.

\section{Analytic Strategy}

All statistical analyses performed for this study were conducted using IBM SPSS 25 for Windows. A moderation analysis was done using PROCESS macro for SPSS by Andrew F. Hayes (2018).

The first stage of the data analysis included descriptive statistics and correlation analysis to gather information about how the variables of interest were related to each other, and to test whether optimism is negatively related to general depressive symptoms in seniors (H1). Next, a moderated moderation method (Model 3, Hayes, 2018) was employed to test H2 and H3.

\section{Results}

\section{Descriptive Statistics and Correlation Analysis}

In order to explore the nature of associations between the examined variables, the aforementioned correlation analysis has been performed. The results of the analysis are presented in Table 1. 
Table 1.

Means, standard deviations, Cronbach's alpha for scale internal reliability and rho-Spearman's correlations between variables in the groups

\begin{tabular}{|c|c|c|c|c|c|c|c|c|c|c|}
\hline & \multicolumn{5}{|c|}{ UTA group } & \multicolumn{5}{|c|}{ NH group } \\
\hline & $M$ & $S D$ & $\alpha$ & 1 & 2 & $M$ & $S D$ & $\alpha$ & 1 & 2 \\
\hline 1. General depression & .22 & .18 & .72 & & & .37 & .21 & .72 & & \\
\hline $\begin{array}{l}\text { 2. Acceptance of } \\
\text { passing }\end{array}$ & 3.59 & .82 & .77 & $-46^{* *}$ & & 4.13 & .72 & .71 & $-23^{* *}$ & \\
\hline 3. Optimism & 3.78 & .87 & .54 & $-68^{* *}$ & $.41^{* *}$ & 3.53 & .80 & .80 & $-26^{* *}$ & $.40^{* *}$ \\
\hline
\end{tabular}

$* *$ Note. $p<.01$

In the UTA group, both acceptance of passing and optimism correlated negatively with general depressive symptoms, whereas optimism correlated positively with acceptance of passing. Similar to the UTA group, in the NH group the level of depressive symptoms negatively correlated with both optimism and acceptance of passing. These correlations were however weaker than in the UTA group. Optimism positively correlated with acceptance of passing and this correlation was of a similar strength to the UTA group.

\section{Moderated Moderation Analysis}

On the second stage, we have tested our hypothesis by employing the method of moderated moderation (Model 3 according to Hayes, 2018). The detailed results of this analysis are presented in Tables 2-3. The tested model proved to be a good fit the data via explaining $37 \%$ variance of the General depression $\left(\mathrm{R}^{2}=.37, \mathrm{MSE}=0.03, \mathrm{~F}(7,94)=8.03\right.$ for $\left.\mathrm{p}<.001\right)$. 
Table 2.

Regression analysis summary for predicting general depression

\begin{tabular}{llllll}
\hline & Coefficient & SE & t & $\mathrm{p}$ & $95 \%$ CI \\
\hline Constant & -1.23 & .77 & -1.60 & .11 & $-2.75 ; .29$ \\
Optimism & .47 & .21 & 2.24 & .03 & $.05 ; .88$ \\
Group & .73 & .26 & 2.84 & .01 & $.22 ; 1.24$ \\
Optimism x Group & -.20 & .07 & -2.74 & .01 & $-.35 ;-.06$ \\
Acceptance of passing & .53 & .24 & 2.25 & .03 & $.06 ; 1.00$ \\
Optimism x Acceptance of passing & -.17 & .06 & -2.74 & .01 & $-.29 ;-.05$ \\
Group x Acceptance of passing & -.20 & .07 & -2.85 & .01 & $-.33 ;-.06$ \\
\hline
\end{tabular}

Furthermore, the highest order of the unconditional interaction for the General depression as the outcome variable for Optimism $\mathrm{x}$ Group $\mathrm{x}$ Acceptance of passing provided $\mathrm{R}^{2}$-change of .06 and $\mathrm{F}(1,94)=9.07$ for $\mathrm{p}<$ .01 . Table 3 presents the details of conditional effects of optimism at values of the group (UTA vs. NH) and the acceptance of passing.

Table 3.

Conditional effects of optimism at values of the group (UTA vs NH) and the acceptance of passing (AP)

\begin{tabular}{lclllll}
\hline & AP level & Effect & $S E$ & $t$ & $\mathrm{p}$ & $95 \%$ CI \\
\hline UTA & 3.2 & -.11 & .03 & -3.51 & .001 & $-.18 ;-.05$ \\
UTA & 4 & -0.16 & .05 & -3.35 & .001 & $-.25 ;-.06$ \\
UTA & 4.8 & -.20 & .07 & -2.9 & .004 & $-.33 ;-.07$ \\
NH & 3.2 & -.18 & .06 & -3.06 & .003 & $-.29 ;-.06$ \\
NH & 4 & -.08 & .03 & -2.46 & .016 & $-.15 ;-.02$ \\
NH & 4.8 & .01 & .04 & 0.23 & .816 & $-.07 ; .09$ \\
\hline
\end{tabular}

Data in Table 3 show that for all levels of acceptance of passing in the UTA, the conditional effect of optimism on general depression was significant. For the $\mathrm{NH}$, the conditional effect of optimism on general 
depression was significant only for low and moderate levels of acceptance of passing.

Figures 1-3 present visualizations of the abovementioned interaction effects for low (Figure 1), moderate (Figure 2) and high (Figure 3) levels of acceptance of passing.

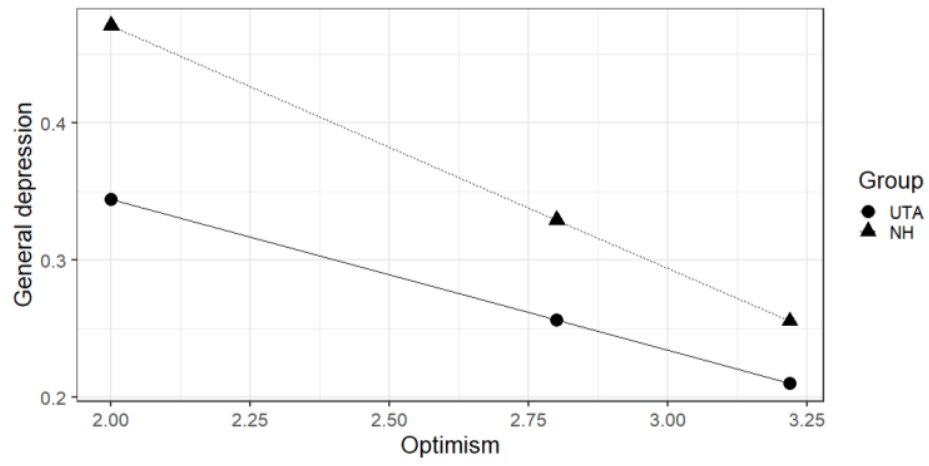

Figure 1. Interaction effects of optimism with general depression by groups and low acceptance of passing

For low acceptance of passing, the interaction effects of optimism with general depression are stronger for the NH group than for the UTA group. Nonetheless both groups showed a similar tendency that higher optimism corresponds with lower general depression.

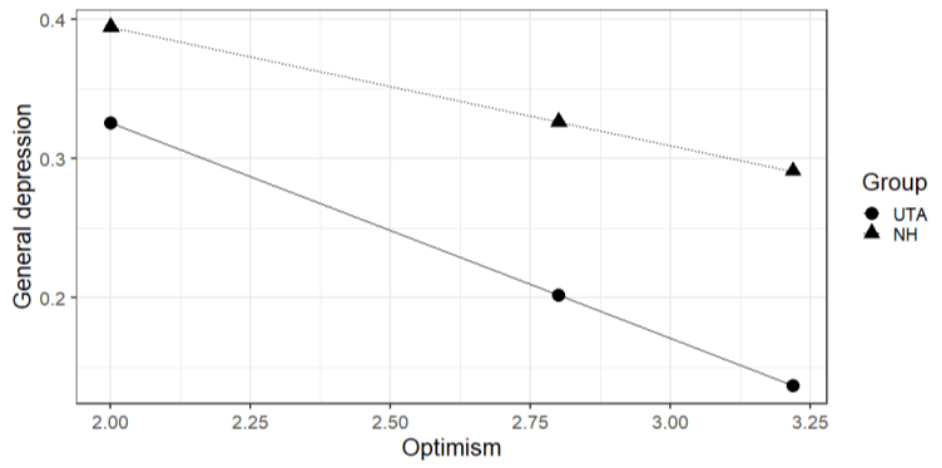

Figure 2 . Interaction effects of optimism with general depression by groups and moderate acceptance of passing 
For moderate level of acceptance of passing, the interaction effects have the same tendency as was shown in Figure 1; however, it is slightly stronger for the UTA group than the NH group.

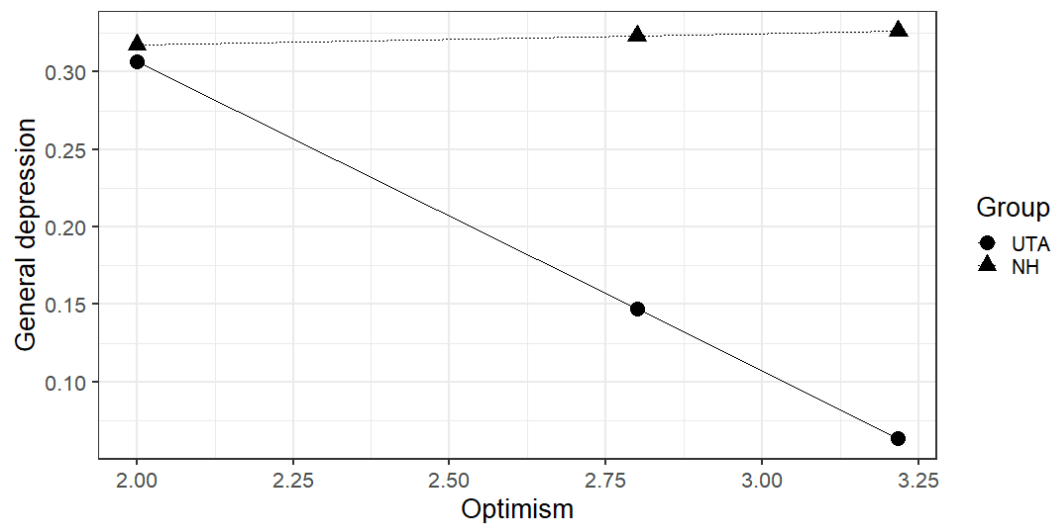

Figure 3. Interaction effects of optimism with general depression by groups and high acceptance of passing

For high level of acceptance of passing, the interaction effects of optimism with general depression are significant for the UTA group. However, the interaction effects for the $\mathrm{NH}$ group appear to be weak with the opposite tendency to what was captured in Figure 1 and 2.

Overall, the analysis of moderated moderation showed interaction effects between optimism and general depression that appeared to have significant differences among groups with a corresponding acceptance of passing. The $\mathrm{NH}$ group showed greater levels of general depression than the UTA group for all levels of optimism and acceptance of passing. Consequently, for the UTA group, with regard to increasing optimism corresponding to a decrease in general depression, this effect was stronger with an increase of acceptance of passing. For the NH group, the tendency was similar to the UTA group for low and moderate acceptance of passing. However, for high acceptance of 
passing in the $\mathrm{NH}$ group, the interaction effect was not statistically significant. The visualization suggests that there was a slight tendency for an increase of optimism to be linked to an increase in general depression.

\section{Discussion}

The aim of this study was to find out whether participation of elderly people in UTA (voluntary) activities versus being a Nursing Home resident may differentiate people in terms of their level of depression. Initially, a correlation analysis was performed to explore the relationships between investigated variables. In the second step, a moderated moderation model was tested with general depression as an outcome variable, with optimism as the focal predictor and acceptance of passing and participation in the abovementioned UTA versus $\mathrm{NH}$ groups as moderators.

Optimism was proven to be generally negatively related to general depressive symptoms in both groups, which is consistent with a large body of previous studies on elderly adults (for instance, Achat et al., 2000; Giltay et al., 2006; Reker, 1997; Robinson-Whelen et al., 1997; Smith et al., 2004). In the NH group, the depressive symptoms were higher than in the UTA group, regardless of the level of acceptance of passing observed. Analyzing the UTA activities' characteristics (Cachioni et al., 2017; Zielińska-Więczkowska, 2017), participation in such a form of leisure time in the elderly age might serve as a factor preventing individuals from developing depressive symptoms due to the (a) freedom of choice of activities undertaken within the scope of participation in UTA; (b) focus on development of skills and knowledge; (c) opportunities to maintain positive social contact with peers, based on learning together and sharing passions. Developing new skills and lifelong development is important to general well-being (Cachioni et al., 2017). The listeners of the University of the Third Age are probably healthier, more efficient, better educated, and more intellectually active, which contributes to the level of life satisfaction.

An active lifestyle reduces the chance of developing depression in elderly adults (Saint Martin, 2017), promoting empowerment and sense of autonomy (for the role of social engagement and empowerment of the elderly see Meshram \& O'Cass, 2013). Previous research suggests that UTA students are likely to participate voluntarily in physical activities (Pieczyńska et al., 2019), so their mental well-being can also be the result of physical activity. 
Moreover, sustaining social contact and making opportunities to interact with others are crucial factors from the social environment which protect against depression (Yang et al., 2018). UTA participation serves as a form of establishing and maintaining positive social contact, especially with peers, which is a source of support (Mackowicz \& Wnek-Gozdek, 2016; Ricardo \& Porcarelli, 2019). However, being the resident of a NH is connected to taking part in activities often directed at compensating for the difficulties in cognitive and physical functioning in elderly life (den Ouden et al., 2017). Such activities are typically designed so as to answer the needs of the residents and bring pleasure (Altintas et al., 2017; Sletteb $\varnothing$ et al., 2017); however, participation in them is not due to the choice of the residents (the day plan is rigid). This difference between UTA students and $\mathrm{NH}$ residents might be responsible for the differences in pathways to developing depressive symptoms, as indicated by our study. It is a finding that suggests that health promotion strategies targeted at the elderly should be varied according to their current life style, place of living and activity level (for a review of challenges regarding health promotion within this age group see Nowakowska, 2017 and Ory et al., 2003).

Acceptance of passing moderated the moderation effect of participation in a particular group (UTA or NH) on the relationship between optimism and depressive symptoms. In the UTA group, the higher the level of optimism, the lower the depressive symptoms, which was consistent for all levels of acceptance of passing. However, for the NH group, the higher the acceptance of passing, the lower the role of optimism in predicting depressive symptoms. In the $\mathrm{NH}$ group of highest level of acceptance of passing, the role of optimism was non-significant in predicting depressive symptoms. The results might suggest that among NH residents, reconciliation with the fact that their lives may soon come to an end is more valid than for UTA listeners, and among $\mathrm{NH}$ residents high on acceptance of passing, an optimistic versus pessimistic attitude toward life does not play a role in developing affective disorders. The results of the above studies are certainly very interesting and can have a real impact on the implementation of the forms of activities proposed for seniors at NHs. In recent years, the offer of activities and additional activities for seniors at NHs in Poland has been expanding (for a review of Nursing Home activities in Poland, see Dobrzyn-Matusiak et al., 2014; Ejdys \& Gedvilaite, 2017). Recently, Nursing Homes in Europe and the US have taken steps to support the elderly not only in terms of compensation, but also in terms of 
mental and emotional health (den Ouden et al., 2015; Froggatt et al., 2017). Our results suggest that this trend should be continued in order to enhance the effect of personal characteristics such as optimism and positive attitude towards the future (including acceptance of passing) on protecting against the development of depressive symptoms.

\section{Limitations and Future Research Directions}

The study has its limitations, which should be taken into account when interpreting its results and planning further studies in the field. Data for the study were collected by a quantitative, self-report, questionnaire-based method. The criterion for being included in analyses was not the age, but participation in UTA or being a resident of NH home, which resulted in an age range over 59, not 60 or 65 as most commonly observed in psychogerontological studies. In the case of the UTA group and Optimism subscale of the resiliency measure, the Cronbach's alpha reliability was .54, which suggests that the results regarding this variable in this group should be treated with caution.

Furthermore, an important limitation of the employed data analysis strategy was the usage of Andrew F. Hayes Model 3 of moderated moderation, which implies that a moderator moderates the effect of another moderator instead of testing the potential moderators independently.

Generally, due to the specific nature of the questions that the used measures contain, self-report may pose a risk of social desirability bias affecting its results. Moreover, the cross-sectional character of the study does not allow for finding out what characteristics of the sample stem from one another (whether higher optimism and acceptance of passing negatively influences depressive symptoms, or whether developing depressive symptoms affects the optimism and acceptance of passing).

Another significant limitation is the significant over-representation of women in the UTA group (81.3\%) and in the NH group (64.8\%), which could affect the results. An important factor is also the characteristics of the research group itself, namely that reduced cognitive performance was possible in some of the participants in the NH group. In contrast, the UTA group could have had very good skills of reading comprehension. The used test was self-report and paper-pencil, and the results might depend on the cognitive skills of respondents. The difference between the groups might have been biased by 
the reading abilities of participants. If further analysis of the problem is undertaken, attention should also be paid to the need for careful selection of respondents in terms of their cognitive abilities. Considering the above limitations resulting from the research carried out for this work, it seems reasonable to use, along with self-description methods, methods of qualitative information acquisition in order to increase the depth of the obtained results. It also seems highly advisable to include persons after prior practical verification of the current state of functioning of cognitive processes.

Another interesting future research avenue in this area could involve a representative sample of seniors in studies to control their ways of spending leisure time, to broaden their understanding of the associations between time spending patterns, optimism, acceptance of passing and depressive symptoms in the elderly age.

\section{Note}

All four authors contributed equally to the study and therefore should be considered first coauthors.

\section{References}

Achat, H., Kawachi, I., Spiro, A., DeMolles, D. A., \& Sparrow, D. (2000). Optimism and depression as predictors of physical and mental health functioning: the Normative Aging Study. Annals of Behavioral Medicine, 22(2), 127-130. https://dx.doi.org/10.1007/BF02895776

Altintas, E., De Benedetto, G., \& Gallouj, K. (2017). Adaptation to nursing home: The role of leisure activities in light of motivation and relatedness. Archives of Gerontology and Geriatrics, 70, 8-13. https://dx.doi.org/10.1016/j.archger.2016.12.004

Anstey, K. J., von Sanden, C., Sargent-Cox, K., \& Luszcz, M. A. (2007). Prevalence and risk factors for depression in a longitudinal, population-based study including individuals in the community and residential care. The American Journal of Geriatric Psychiatry, 15(6), 497-505. https://dx.doi.org/10.1097/jgp.0b013e31802e21d8

Arbinaga, I. F. (2003). Personas mayores institucionalizadas versus no institucionalizadas: aspectos diferenciales en ansiedad ante la muerte, depresión y satisfacción con la vida. Mapfre Medicina, 14, 258-264. 
Beutel, M., Glaesmer, H., Decker, O., Fischbeck, S., \& Brahler, E. (2009). Life satisfaction, distress and resiliency across the life span of women. Menopause, 16(6),

1132-1138. https://dx.doi.org/10.1097/gme.0b013e3181a857f8

Blazer, D. G. (2009). Depression in late life: review and commentary. Focus, 7(1), 118-136.

Block, J., \& Kremen, A. M. (1996). IQ and ego-resiliency: Conceptual and empirical connections and separateness. Journal of Personality and Social Psychology, 70(2), 349-361. https://dx.doi.org/10.1037/00223514.70.2.349

Brown, M. N., L. K., \& Luisi, A. F. (2002). The management of depression in older nursing home residents. Journal of the American Geriatrics Society, 50(1), 69-76. https://dx.doi.org/10.1046/j.15325415.2002.50010.x

Brudek, P.J., Krok, D., Sękowski, M., \& Steuden, S. (2019). The Health Assessment as a Moderator in the Relationship Between the Religious Meaning System, Personal Meaning Profile and Attitude Towards Death Among Polish Older Adults. In: M. Saad, R. de Medeiros (eds), An Examination of Religiosity: Influences, Perspectives and Health Implications. New York: Nova Science Publishers.

Cachioni, M., Delfino, L. L., Yassuda, M. S., Batistoni, S. S., Melo, R. C., \& Domingues, M. A. (2017). Subjective and psychological well-being among elderly participants of a University of the Third Age. Revista Brasileira de Geriatria e Gerontologia, 20(3), 340-351. https://dx.doi.org/10.1590/1981-22562017020.160179

Carver, C. S., Scheier, M. F., \& Segerstrom, S. C. (2010). Optimism. Clinical Psychology Review, 30(7), 879-889. https://dx.doi.org/10.1016/j.cpr.2010.01.006

Charney, D. S. (2004). Psychobiological mechanisms of resilience and vulnerability: implications for successful adaptation to extreme stress. American Journal of Psychiatry, 161(2), 195-216. https://dx.doi.org/10.1176/appi.ajp.161.2.195

Chiang, K. J., Chu, H., Chang, H. J., C. M., Chen, C. H., Chiou, H. Y., \& Chou, K. R. (2010). The effects of reminiscence therapy on psychological well-being, depression, and loneliness among the institutionalized aged. International Journal of Geriatric Psychiatry, 25(4), 380-388. https://dx.doi.org/10.1002/gps.2350 
Chung, H. (2008). Resiliency and character strengths among college students. The University of Arizona. Retrieved from https://repository.arizona.edu/handle/10150/195507. https://dx.doi.org/ 10.13140/RG.2.2.17897.19040

Daaleman, T. P., \& Dobbs, D. (2010). Religiosity, spirituality, and death attitudes in chronically ill older adults. Research on Aging, 32(2), 224-243. https://dx.doi.org/10.1177/0164027509351476

den Ouden, M. B., Meijers, J. M., Zwakhalen, S. M., Braun, S. M., Tan, F. E., \& Hamers, J. P. (2015). Daily (in) activities of nursing home residents in their wards: an observation study. Journal of the American Medical Directors Association, 16(11), 963-968. https://dx.doi.org/10.1016/j.jamda.2015.05.016

den Ouden, M., Kuk, N. O., Zwakhalen, S. M., Bleijlevens, M. H., Meijers, J. M., \& Hamers, J. P. (2017). The role of nursing staff in the activities of daily living of nursing home residents. Geriatric Nursing, 38(3), 225-230. https://dx.doi.org/10.1016/j.gerinurse.2016.11.002

Deręgowska, J. (2014). Elderly people and their perception of life and its quality in respect to passing away and inevitability of death - selected aspects. Gerontologia Polska, 4, 97-158.

Diener, E., Lucas, R. E., Oishi, S., \& Suh, E. M. (2002). Looking up and looking down: Weighting good and bad information in life satisfaction judgements. Personality and Social Psychology Bulletin, 28(4), 437-445. https://dx.doi.org/10.1177/0146167202287002

Djernes J. K. (2006) Prevalence and predictors of depression in populations of elderly. Acta Psychiatrica Scandinavica, 113(5), 372-387. https://dx.doi.org/10.1111/j.1600-0447.2006.00770

Dobrzyn-Matusiak, D., Marcisz, C., Bąk, E., Kulik, H., \& Marcisz, E. (2014). Physical and mental health aspects of elderly in social care in Poland. Clinical Interventions in Aging, 9, 1793. https://dx.doi.org/10.2147/CIA.S69741

Dupuis, S. L., \& Smale, B. J. (1995). An examination of relationship between psychological well-being and depression and leisure activity participation among older adults. Loisir et société/Society and Leisure, $\quad$ 18(1), 67-92. https://dx.doi.org/10.1080/07053436.1995.10715491

Duy, B., \& Y1ldiz, M. A. (2019). The mediating role of self-esteem in the relationship between optimism and subjective well-being. Current Psychology, 38(6), 1456-1463. 
Ejdys, J., \& Gedvilaite, D. (2017). Learning orientation in nursing homes in Poland. Engineering Management in Production and Services, 9(3), 51-62. https://dx.doi.org/10.2307/2393553

Erikson, E. H. (1968). Identity. Youth and crisis. New York: Norton.

Erikson, E. H. (1982). The life cycle completed. New York: Norton.

Feifel, H. (1990). Psychology and death: Meaningful rediscovery. American Psychologist, 45(4), 537. https://dx.doi.org/10.1037/0003066X.45.4.537

Fidecki, W., Wysokiński, M., Wrońska, I., Misiarz, J., Kulina, D., \& Kuszplak, K. (2019). Risk assessment of depression among the elderly from a rural environment. Geriatria, 13, 147-151.

Fine, J. (2001). The effect of leisure activity on depression in the elderly: Implications for the field of occupational therapy. Occupational Therapy in Health Care, 13(1), 45-59. https://dx.doi.org/10.1080/J003v13n01_04

Fitzgerald T., Tennen H., Affleck G., \& Pransky G. (1993) The relative importance of dispositional optimism and control appraisals in quality of life after coronary artery bypass surgery. Journal of Behavioral Medicine 16, 25-43.

Formosa, M. (2010). Universities of the Third Age: A rationale for transformative education in later life. Journal of Transformative Education, $\quad 8(3)$,

197-219.

https://dx.doi.org/10.1177/1541344611419857

Formosa, M. (2014). Four decades of Universities of the Third Age: past, present, future. Ageing \& Society, 34, 42-66. https://dx.doi.org/10.1017/S0144686X12000797

Fredrickson, B. (2001). The role of positive emotions in positive psychology: The broaden and build theory of positive emotions. American Psychologist, 56(3), 218- 226. https://dx.doi.org/10.1037//0003066X.56.3.218

Froggatt, K., Payne, S., Morbey, H., Edwards, M., Finne-Soveri, H., Gambassi, G., ... \& Van den Block, L. (2017). Palliative care development in European care homes and nursing homes: application of a typology of implementation. Journal of the American Medical Directors Association, 18(6), 550-e7. https://dx.doi.org/10.1016/j.jamda.2017.02.016

Giltay, E. J., Zitman, F. G., \& Kromhout, D. (2006). Dispositional optimism and the risk of depressive symptoms during 15 years of follow-up: the 
Zutphen Elderly Study. Journal of Affective Disorders, 91(1), 45-52. https://dx.doi.org/10.1016/j.jad.2005.12.027

Harris, Y., \& Cooper, J. K. (2006). Depressive symptoms in older people predict nursing home admission. Journal of the American Geriatrics Society, 54(4), 593-597. https://dx.doi.org/10.1111/j.15325415.2006.00687.x

Hayes, A. F. (2018). Introduction to mediation, moderation, and conditional process analysis: A regression-based approach. New York: Guilford Publications.

Heikkinen, R., \& Kauppinen, M. (2004). Depressive symptoms in late life: A 10-years follow-up. Archives of Gerontology and Geriatrics, 38, 239250. https://dx.doi.org/10.1016/j.archger.2003.10.004

Hoover, D. R., Siegel, M., Lucas, J., Kalay, E., Gaboda, D., Devanand, D. P., \& Crystal, S. (2010). Depression in the first year of stay for elderly long-term nursing home residents in the USA. International Psychogeriatrics, 22(7), 1161-1171. https://dx.doi.org/10.1017/S1041610210000578

Irigaray, T. Q., \& Schneider, R. H. (2007). Prevalência de depressão em idosas participantes da Universidade para a Terceira Idade. Revista de Psiquiatria do Rio Grande do Sul, 29(1), 19-27. https://dx.doi.org/10.1590/S0101-81082007000100008

Iyer, R., Reisenwitz, T. H., \& Eastman, J. K. (2008). The impact of cognitive age on seniors' lifestyles. Marketing Management Journal, 18(2), 106-118.

Kasl-Godley, J. E., Gatz, M., \& Fiske, A. (1998). Depression and depressive symptoms in old age. In I. Nordhus, G. Van den Bos, S. Berg, \& P. Fromholt (Eds.), Clinical geropsychology (pp. 211-217). Washington, DC: APA. https://dx.doi.org/10.1146/annurev.clinpsy.032408.153621

Lonetto, R., \& Templer, D. I. (1986). Death anxiety. Hemisphere Publishing Corp.

Mackowicz, J., \& Wnek-Gozdek, J. (2016). "It's never too late to learn"-How does the Polish U3A change the quality of life for seniors? Educational Gerontology, 42(3), 186-197. https://dx.doi.org/10.1080/03601277.2015.1085789

Makselon, J. (1987). Orientacja temporalna a postawa wobec śmierci. Analecta Cracoviensia, 19, 471-485. https://dx.doi.org/10.15633/acr.3050 
Mamplekou, E., Bountziouka, V., Psaltopoulou, T., Zeimbekis, A., Tsakoundakis, N., Papaerakleous, N., ..., \& Panagiotakos, D. (2010). Urban Environment, Physical Inactivity and Unhealthy Dietary Habits Correlate to Depression Among Elderly Living in Eastern Mediterranean Islands: The MEDIS (MEDiterranean ISlands Elderly) Study. The Journal of Nutrition, Health and Aging, 14(6), 449-455. https://dx.doi.org/10.1007/s12603-010-0091-0

Maruta, T., Colligan, R. C., Malinchoc, M., \& Offord, K. P. (2000). Optimists vs pessimists: Survival rate among medical patients over a 30 -year period. Mayo Clinical Proceedings, 75(2), 140-143. https://dx.doi.org/10.4065/75.2.140.

Mercês, C. A. M. F., Souto, J. D. S. S., Zaccaro, K. R. L., de Souza, J. F., Primo, C. C., \& Brandão, M. A. G. (2019). Death Anxiety: Concept Analysis and Clarification of Nursing Diagnosis. International Journal of Nursing Knowledge. https://doi.org/10.1111/20473095.12260

Meshram, K., \& O'Cass, A. (2013). Empowering senior citizens via third places: research driven model development of seniors' empowerment and social engagement in social places. Journal of Services Marketing, 27(2), 141-154. https://doi.org/10.1108/08876041311309261

Mohammadpour, A., Sadeghmoghadam, L., Shareinia, H., Jahani, S., \& Amiri, F. (2018). Investigating the role of perception of aging and associated factors in death anxiety among the elderly. Clinical Interventions in Aging, 13, 405-410. https://dx.doi.org/10.2147/CIA.S150697

Moreno, R. P., De La Fuente Solana, E. I., Rico, M. A., \& Fernández, L. M. (2009). Death anxiety in institutionalized and non-institutionalized elderly people in Spain. OMEGA-Journal of Death and Dying, 58(1), 61-76. https://dx.doi.org/10.2190/OM.58.1.d

Nowakowska, I. (2017). Challenges of overcoming ageism towards elderly people in healthcare context. Horyzonty Wychowania, 16(40), 9-24. https://dx.doi.org/10.17399/HW.2017.164001

Ogińska-Bulik, N. (2014). Prężność psychiczna a zadowolenie z życia osób uzależnionych od alkoholu. Alkoholizm i Narkomania, 27(4), 319324. https://dx.doi.org/10.1016/S0867-4361(14)70023-9

Ogińska-Bulik, N., \& Juczyński, Z. (2008). Skala pomiaru prężności - SPP25. Nowiny Psychologiczne, 3, 39-56. 
Ogińska-Bulik, N., \& Juczyński, Z. (2010). Osobowość, stres a zdrowie. Warszawa: Difin.

Ogińska-Bulik, N., \& Juczyński, Z. (2011). Prężność u dzieci i młodzieży: charakterystyka i pomiar - polska skala SPP-18. Polskie Forum Psychologiczne, 16(1), 7-28.

Ondrakova, J. (2014). Education of seniors at universities of the third age. International Multidisciplinary Scientific Conference on Social Sciences and Arts SGEM2014, 3, pp. 257-264. https://dx.doi.org/10.5593/SGEMSOCIAL2014/B13/S3.035

Ory, M., Hoffman, M.K., Hawkins, M., Sanner, B., \& Mockenhaupt, R. (2003). Challenging aging stereotypes. Strategies for creating a more active society. American Journal of Preventive Medicine, 25(3), 164-171. https://dx.doi.org/10.1016/s0749-3797(03)00181-8

Pieczyńska, A., Zasadzka, E., Trzmiel, T., \& Pawlaczyk, M. (2019). Physical activity, physical fitness and quality of life of the University of the Third Age Students. Medical Science Pulse, 13(3), 10-15. https://dx.doi.org/10.5604/01.3001.0013.5540

Poprawa R. (2001). Zasoby osobiste w radzeniu sobie ze stresem. In G. Dolińska-Zygmunt (ed.) Elementy psychologii zdrowia. Wrocław: Wydawnictwo Uniwersytetu Wrocławskiego.

Pot, A. M., Bohlmeijer, E. T., Onrust, S., Melenhorst, A. S., Veerbeek, M., \& De Vries, W. (2010). The impact of life review on depression in older adults: a randomized controlled trial. International Psychogeriatrics, 22(4), 572-581. https://dx.doi.org/10.1017/S104161020999175X

Reker, G. T. (1997). Personal meaning, optimism, and choice: Existential predictors of depression in community and institutional elderly. The Gerontologist, $37(6)$, 709-716. https://dx.doi.org/10.1093/geront/37.6.709

Ricardo, R., \& Porcarelli, A. (2019). Education and socialisation in later life: The case of a University of Third Age in Portugal. European Journal for Research on the Education and Learning of Adults, 10(3), 247260. https://dx.doi.org/10.3384/rela.2000-7426.rela20197

Robinson-Whelen, S., Kim, C., MacCallum, R. C., \& Kiecolt-Glaser, J. K. (1997). Distinguishing optimism from pessimism in older adults: Is it more important to be optimistic or not to be pessimistic? Journal of Personality and Social Psychology, 73(6), 1345-1353. https://dx.doi.org/10.1037/0022-3514.73.6.1345 
Rodda J., Walker Z., \& Carter J. (2011). Depression in older adults. BMJ, 343, d5219. https://dx.doi.org/10.1136/bmj.d5219

Saint Martin, M., Sforza, E., Barthélémy, J. C., Roche, F., Lefèvre, P., Liénard, G., \& Thomas-Anterion, C. (2017). Long-lasting active lifestyle and successful cognitive aging in a healthy elderly population: The PROOF cohort. Revue Neurologique, 173(10), 637644. https://dx.doi.org/10.1016/j.neurol.2017.05.009

Salguero, A., Martínez-García, R., Molinero, O., \& Márquez, S. (2011). Physical activity, quality of life and symptoms of depression in community-dwelling and institutionalized older adults. Archives of Gerontology and Geriatrics, 53(2), 152-157. https://dx.doi.org/10.1016/j.archger.2010.10.005

Sethi S., \& Seligman M. (1993), Optimism and fundamentalism. Psychological Science, 4(4), 256-259.

Sękowski, M. (2020). Attitude Toward Death From the Perspective of Erik Erikson's Theory of Psychosocial Ego Development: An Unused Potential. OMEGA-Journal of Death and Dying. https://doi.org/10.1177/0030222820921604

Sheikh, J. I., \& Yesavage, J. A. (1986). Geriatric Depression Scale (GDS): recent evidence and development of a shorter version. Clinical Gerontologist: The Journal of Aging and Mental Health, 5(1-2), 165173. https://dx.doi.org/10.1300/J018v05n01_09

Sivertsen, H., Bjørkløf, G. H., Engedal, K., Selbæk, G., \& Helvik, A. S. (2015). Depression and quality of life in older persons: a review. Dementia and Geriatric Cognitive Disorders, 40(5-6), 311-339. https://dx.doi.org/10.1159/000437299

Sletteb $\varnothing$, A., Sæteren, B., Caspari, S., Lohne, V., Rehnsfeldt, A. W., Heggestad, A. K., . . ., \& Nåden, D. (2017). The significance of meaningful and enjoyable activities for nursing home resident's experiences of dignity. Scandinavian Journal of Caring Sciences, 31(4), 718-726. https://dx.doi.org/10.1111/scs.12386

Smith, N., Young, A., \& Lee, C. (2004). Optimism, health-related hardiness and well-being among older Australian women. Journal of Health Psychology, 9(6), 741-752. https://dx.doi.org/10.1177/1359105304045373

Thomas, J. B., \& Peters, C. L. (2009). Silver seniors: Exploring the selfconcept, lifestyles, and apparel consumption of women over age 65. 
International Journal of Retail \& Distribution Management, 37(12), 1018-1040. https://dx.doi.org/10.1108/09590550911005001

Villar, F., \& Celdrán, M. (2012). Generativity in older age: A challenge for universities of the third age (U3A). Educational Gerontology, 38(10), 666-677. https://dx.doi.org/10.1080/03601277.2011.595347

Volicer, L., Frijters, D. H., \& Van der Steen, J. T. (2012). Relationship between symptoms of depression and agitation in nursing home residents with dementia. International Journal of Geriatric Psychiatry, 27(7), 749-754. https://dx.doi.org/10.1002/gps.2800

Wang J., Lin Y., \& Hsieh L. (2011) Effects of gerotranscendence support group on gerotranscendence perspective, depression, and life satisfaction of institutionalized elders. Aging \& Mental Health, 15(5), 580-586. https://dx.doi.org/abs/10.1080/13607863.2010.543663

Werner, E. E. (1993). Risk, resilience and recovery: Perspectives from the Kauai longitudinal study. Developmental Psychopathology, 5(4), 503-515. https://dx.doi.org/10.1017/S095457940000612X

World Health Organization (WHO) (2019). ICD-11. Geneva: WHO. Available from: https://icd.who.int/browse11/l-m/en

Yang, J., Park, E. C., Lee, S. A., Lee, J. E., Choi, D. W., Chae, W., \& Jang, S. I. (2018). The association between social contacts and depressive symptoms among elderly Koreans. Psychiatry Investigation, 15(9), 861-868. https://dx.doi.org/10.30773/pi.2018.06.28.1

Zadworna, M., Idczak-Paceś, E., Gołygowska, A., \& Kossakowska, K. (2019). Health behaviors of institutionalized older adults [Research data]. https://dx.doi.org/10.17605/OSF.IO/M8K2T

Zadworna-Cieślak, M. (2017). Developmental tasks' attainment in late adulthood - the construction of a new psychometric tool. Gerontologia Polska, 25, 156-162.

Zadworna-Cieślak, M. (2019). Psychometric properties of the Developmental Tasks Questionnaire for Seniors. Current Psychology. https://dx.doi.org/10.1007/s12144-019-00380-0

Zadworna-Cieślak, M., \& Ogińska-Bulik, N. (2019). Satisfaction with life in old age - the role of developmental tasks attainment and resiliency. Przegląd Badań Edukacyjnych/Educational Studies Review, 28(1), 23-35. http://dx.doi.org/10.12775/PBE.2019.002

Zielińska-Więczkowska, H. (2017). Correlations between satisfaction with life and selected personal resources among students of Universities of 
the Third Age. Clinical Interventions in Aging, 12, 1391-1399. https://dx.doi.org/10.2147/CIA.S141576

Zielińska-Więczkowska, H., Kędziora-Kornatowska, K., \& Ciemnoczołowski, W. (2011). Evaluation of quality of life (QoL) of students of the University of Third Age (U3A) on the basis of sociodemographic factors and health status. Archives of Gerontology and Geriatrics, $53(2)$, 198-202. https://dx.doi.org/10.1016/j.archger.2010.09.003

Edyta Idczak-Paceś. PhD Candidate. The Maria Grzegorzewska University, Institute of Psychology, Warsaw (Poland).

Adrian Kabat. PhD Candidate. The Maria Grzegorzewska University, Institute of Psychology, Warsaw (Poland).

Adrianna Krzywik. PhD Candidate. The Maria Grzegorzewska University, Institute of Philosophy and Sociology, Warsaw (Poland).

Iwona Nowakowska. PhD Candidate. The Maria Grzegorzewska University, Institute of Psychology, Warsaw (Poland).

Contact Address: eisd7 @aps.edu.pl. The Maria Grzegorzewska University, Institute of Psychology, Szczęśliwicka 40, 02-353 Warsaw (Poland). 